\title{
GAMBARAN PERILAKU DISIPLIN BERLALU LINTAS DAN PENYEBAB KECELAKAAN LALU LINTAS DI JALAN NASIONAL KOTA SAMARINDA
}

\author{
Tiopan H.M. Gultom \\ Fakultas Teknik, Universitas Mulawarman \\ Jalan Sambaliung No.9, Samarinda Utara \\ Kota Samarinda, Kalimantan Timur \\ tiopan@unmul.ac.id \\ Tri Tjahjono \\ Fakultas Teknik, Universitas Indonesia \\ Kampus UI Baru, Depok \\ Jawa Barat \\ tri.tjahjono@ui.ac.id
}

\author{
Lisda Sofia \\ Fakultas Ilmu Sosial dan Ilmu Politik, Program Studi \\ Psikologi, Universitas Mulawarman \\ Jalan Tanah Grogot No.1, Samarinda Utara \\ Kota Samarinda, Kalimantan Timur \\ lisdasofia@yahoo.com \\ Sonya Sulistyono \\ Fakultas Teknik, Universitas Jember \\ Jalan Kalimantan 37 Jember \\ Jawa Timur \\ sonya.sulistyono@unej.ac.id
}

\begin{abstract}
Abstrak
Tujuan penelitian adalah mengetahui bagaimana gambaran tingkat perilaku disiplin berlalu lintas dan faktor penyebab laka lantas yang terjadi di jalan nasional Wilayah Kota Samarinda tahun 2019 Provinsi Kalimantan Timur. Penelitian menggunakan metode campuran (mixed methods research). Metode penelitian kuantitatif yang digunakan adalah tipe survey deskriptive sedangkan kualitatif menggunakan tipe studi kasus. Metode pengumpulan data dalam penelitian ini menggunakan skala perilaku disiplin berlalu lintas dan dokumentasi yang didapatkan dari unit Laka Lantas Polresta Samarinda. Hasil penelitian survey menunjukkan bahwa subjek penelitian cenderung memiliki perilaku disiplin lalu lintas yang paling dominan berada pada kategori tinggi dengan sebanyak 203 responden atau sekitar 60.4 persen. Jika dilihat hasil dokumentasi, penyebab laka lantas disebabkan beberapa faktor. Pertama, aspek kurangnya kualitas individu pengendara. Kedua ,aspek kurangnya penataan kendaraan. Ketiga, kurangnya kesadaran untuk berhati-hati di jalan raya. Oleh sebab itu dapat disimpulkan faktor utama penyebab terjadinya laka lantas adalah faktor manusianya.
\end{abstract}

Kata kunci: perilaku disiplin berlalu lintas, kecelakaan lalu lintas

\begin{abstract}
Abstrak
study the purpose of this is to find out how the level of traffic discipline behavior and the factors that cause it to occur on the national road Samarinda City in 2019 East Kalimantan Province. Research using mixed methods research. Quantitative research methods used are descriptive survey type while qualitative uses the case study type. The data collection method in this study uses a scale of traffic discipline behavior and documentation obtained from the Samarinda Police Traffic Unit. The survey results showed that the research subjects tended to have the most dominant traffic discipline behavior in the high category with as many as 203 respondents or around 60.4 percent. If you see the results of the documentation, the cause was then caused by several factors. First, the aspect of the lack of individual rider quality. Second, the aspect of lack of vehicle structuring. Third, the lack of awareness of the arrangement of roads and traffic signs. This can be concluded and in accordance with the documentation data only and then the main factor causing laka then is the human factor.
\end{abstract}

Kata kunci: traffic discipline behavior, traffic accident 


\section{LATAR BELAKANG}

Era sekarang ini adanya laju pertumbuhan angka kendaraan bermotor maupun sering kita sebut dengan lalu lintas, seiring dengan hal tersebut maka menyebabkan adanya permasalahan lalu lintas di jalan, sehingga hal tersebut menjadi sorotan utama dalam masalah ruang lingkup nasional. Berdasarkan berita yang dikutip langsung dari berita dan informasi dari Bin.go.id tahun 2013 menjelaskan bahwa pada tahun 2011 terjadi kecelakaan sebanyak 109.776 kasus sehingga mengakibatkansebanyak 31.185 orang meinggal dunia, kemudian di tahun 2012 sebanyak 109.038 kasus kecelakaan yang mengakibatkan 27.441 orang meninggal dunia. Jika dilihat dari usia sekitar $41 \%$ korban kecelakaan lalu lintas jalan berusia 16-30 tahun. Jika dilihat dari penyebab kecelakaan sebesar $42 \%$ terjadi dikarenakan pengemudi dijalan raya mengemudikan kendaraanya secara ugal-ugalan selain itu kecelakan terjadi karena faktor kelelahan dan mengantuk. Selain itu berdasarkan berita yang dikutip dari Kompas.com pada tahun 2018 jumlah kecelakaan lalu lintas sebanyak 107.968 kasus, secara perhitungan dari tahun 2014-2019 korban kecelakaan yang meninggal dunia sebanyak 30.000 korban pertahun, sehingga jika jika dihitung sebanyak 80 orang per hari yang meninggl dunia akibat kecelakaan (Maulana, 2019).

Berdasarkan data yang dikutip dari prokaltim, Polresta Samarinda mencatat kecelakaan lalu lintas mengalami kenaikan tahun 2018 sebanyak 277 kasus dibandingkan tahun sebelumnya 2017 mencapai 269 kasus. Sebanyak 55 orang meninggal dunia, sebanyak 82 orang luka ringan, dan sebanyak 84 orang luka ringan. Kecelakaan tersebut disebabkan banyaknya pengendara yang melalaikan aturan tatat tertib lalu lintas

Penyebab kecelakaan dilalu lintas sebagian besar karena adanya sikap yang dimiliki oleh pengendara bermotor yaitu sikap melanggar tata tertib berlalu lintas, sehingga dapat mengakibatkatkan adanya bahaya keselamatan bagi pengendara lain atau pengguna jalan. Sehingga perlu adanya kedisiplinan dalam berlalu lintas yang diterapkan oleh pengguna jalan khususnya pengendera bermotor.

Menurut Hidayah (2015) disiplin dalam berlalu lintas adalah bentuk perilaku penggendara bermotor dalam berlalu lintas yaitu mentaati tata tertib, dengan adanya pentaatan tata tertib maka menyebabkan adanya proses belajar yang dialami oleh pengendara bermotor. Sehingga akan membuat kondisi berlalu lintas menjadi aman serta terkendali. Masyarakat yang sudah terbiasa dalam tertib berlalu lintas cenderung dapat menekan terjadinya tingkat kecelakaan karena adanya disiplin berlalu lintas.

Berkendara di jalan raya harus menerapkan disiplin lalu lintas, sehingga dapat dikatakan baik penggunaan jalannya. Salah satu langkah peningkatan kualitas pemakai jalan adalah dengan memberikan pengetahuan tentang tertib lalu lintas. Untuk itu perlu adanya pembinaan dan pembelajaran mengenai pengetahuan tentang tertib lalu lintas di sekolah sebagai pengetahuan yang wajib diberikan. Hal tersebut penting diberikan karena dapat membentuk kepribadian seseorang. Penanaman norma dalam penerapkan pentingnya berlalu lintas yang ditanamkan orang tua, guru dan masyarakat akan digunakan sebagai kerangka acuan bagi penerapan disiplin lalu lintas. Hal tersebut terbukti dari adanya kecenderungan yang menunjukkan bahwa seseorang yang hampir tidak pernah mengalami kecelakaan disebabkan karena mendapatkan penanaman pengetahuan tetantang nilai nilai berperilaku aman (Ahmadi, 1994). 
Priambodo (1997) mengemukakan faktor yang dapat menyebabkan adanya peningkatakan disiplin berlalu lintas adalah pendidikan. Adanya pendidikan berupa non formal seperti sosialisasi kepada masyarakat tentang pentingnya keselamatan berlalu lintas, kemudian bagaimana pentingnya taat tertib belalu lintas sangat penting diberikan. Begitu juga dengan adanya sosialiasi kepada sekolah. Pembentukan sikap berlalu lintas dapat dikatakan bisa dimulai dari adanya pembentukan disiplin sejak dini kepada siswa.

Berdasarkan permasalah yang telah dikemukakan perlu dilakukannya penelitian mengenai bentuk gambaran perilaku disiplin berlalu lintas serta penyebab kecelakaan di jalan nasional kota Samarinda.

\section{TINJAUAN PUSTAKA}

\section{Perilaku Disiplin Berlalu Lintas}

Menurut Sari dan Widodo (2014) menyatakan perilaku disiplin berlalu lintas adalah suatu sikap dalam menggambarkan kondisi yang tercipta sehingga membentuk proses dari serangkaian perilaku yang menunjukkan adanya nilai-nilai ketaatan, kepatuhan, kesetiaan, keteraturan dan ketertiban berkendara di jalan raya. Jika memiliki kedisplinanakan membuat seseorang untuk menjadi terlatih dalam mengontrol dirinya dalam berkendara, di jalan raya

Sementara itu menurut Hidayah (2015) mengemukakan perilaku disiplin berlalu lintas adalah suatu bentuk yang dirasakan oleh pengendara bermotor dalam ber tanggung jawab terhadap peraturan atau norma yang ada di jalan raya dan hal tersebut merupakan proses belajar yang dirasakan masyarakat sebagai pengendara bermotor untuk mampu menghasilkan suasana berlalu lintas yang aman, lancer, dan terkendali. Sehingga dapat disimpulkan bahwa kesadaran dalam disiplin berlalu lintas perlu sejak dini harus dimulai dilakukan disekolah adalah salah satu langkah yang sangat tepat serta positif untuk memberikan pemahaman kepada pelajar agar berhati-hari di jalan raya.

Menurut Ancok (2004), aspek perilaku disiplin berlalu lintas ada tiga berikut penjelasannya:

\section{Kualitas Individu}

Kualitas individu adalah bagaimana seorang pengendara bermotor mampu mejaga keamanan dan keselamatan dalam berkendara di jalan raya dengan mentaati ketertiban lalu lintas

2. Penataan Kendaraan

Penataan kendaraan meliputi kelengkapan kendaraan bermotor yaitu helem, lampu, dan kaca spion, hal tersebut adalah sebagai safety bagi pengguna kendaraan bermotor untuk aman berkendara di jalan raya

3. Penataan Jalan dan Rambu Lalu Lintas

Penataan jalan dan rambu lalu linta seperti adanya tata jalan dan rambu lalu lintas yang merupakan awal dari penataan ketertiban lalu lintas.

\section{Penyebab Kecelakaan Lalu Lintas}

Menurut Hobs dalam Azizirrahman, (2015) mengemukakan bahwa ada 3 faktor penyebab kecelakaan lalu lintas yaitu: 
1. Manusia

Manusia (pengendara bermotor) dapat membawa kendaraan dengan kecepatan tinggi/ ugal-ugalan, kemudian membawa dengan muatan yang berlebihan serta manusia dapat tidak tertib (tidak memakai helm dan melanggar rambu lalu lintas dan marka jalan)

2. Kendaraan

Faktor kedua adalah adanya kelengkapan kendaraan seperti kaca spion kemudian lampu kendaraan (lampu utama, lampu indikator/sein dan lampu rem).

3. Faktor lingkungan fisik jalan

Faktor yang ketiga adalah karena adanya faktor jalan/lingkungan sepertijalan rusak, jalan berlubang, jalan tergenang, jalan gelap, tanpa marka/rambu jalan dan tikungan tajam, hal tersebut cenderung sebagai penyebab terjadinya kecelakaan

\section{Metode Penelitian}

Jenis penelitian ini adalah metode campuran (mixed methods research) adalah suatu prosedur untuk mengumpulkan, menganalisis, dan mencampur metode kuantitatif dan kualitatif dalam suatu penelitian atau serangkaian penelitian untuk memahami permasalahan penelitian (Creswel dan Clark, 2011). Metode peneltian kuantitatif yang digunakan adalah tipe survey deskriptive sedangkan kualitatif menggunakan tipe studi kasus. Metode pengumpulan data dalam penelitian ini menggunakan skala perilaku disiplin berlalu lintas dan dokumentasi yang didapatkan dari unit Laka Lantas Polresta Samarinda.

\section{Hasil Penelitian dan Pembahasan}

Adapun hasil penelitian yang didapatkan dari survey perilaku disiplin berlalu lintas adalah sebagai berikut :

Tabel 1. Kategorisasi skor perilaku disiplin berlalu lintas

\begin{tabular}{cccc}
\hline Skor & Kategori & F & Persentase \\
\hline$\geq 86$ & Sangat Tinggi & 94 & 28 \\
\hline $72-85$ & Tinggi & 203 & 60.4 \\
\hline $59-71$ & Sedang & 38 & 11.3 \\
\hline $46-58$ & Rendah & 1 & 0.3 \\
$\leq 45$ & Sangat Rendah & 0 & 0 \\
\hline
\end{tabular}

Berdasarkan survey yang telah dilakukan, maka dapat dilihat bahwa masyarakat cenderung memiliki rentang nilai skala perilaku disiplin lalu lintas yang paling dominan berada pada kategori tinggi dengan rentang nilai 72 - 85 dan frekuensi sebanyak 203 masyarakat atau sekitar 60.4 persen. Hal ini menunjukkan masyarakat Kota Samarinda Provinsi Kalimantan Timur memiliki perilaku disiplin berlalu lintas yang tinggi.

Selanjutnya hasil survey masing-masing aspek atau indikator dari perilaku disiplin berlalu lintas pertama aspek kualitas individu adalah sebagai berikut: 
Tabel 2. Kategorisasi skor indikator kualitas individu

\begin{tabular}{cccc}
\hline Skor & Kategori & F & Persentase \\
\hline$\geq 21$ & Sangat Tinggi & 73 & 21.7 \\
$17-20$ & Tinggi & 231 & 68.8 \\
\hline $14-16$ & Sedang & 31 & 9.2 \\
\hline $11-13$ & Rendah & 0 & 0 \\
\hline$\leq 10$ & Sangat Rendah & 1 & 0.3 \\
\hline
\end{tabular}

Dapat dilihat bahwa masyarakat cenderung memiliki rentang nilai untuk indikator kualitas individu dari skala perilaku disiplin lalu lintas yang paling dominan berada pada kategori tinggi dengan rentang nilai 17 - 20 dan frekuensi sebanyak 231 masyarakat atau sekitar 68.8 persen. Hal ini menunjukkan masyarakat Kota Samarinda Provinsi Kalimantan Timur memiliki kualitas individu dalam berkendara yang tergolong tinggi.

Tabel 3. Kategorisasi skor indikator penataan kendaraan

\begin{tabular}{cccc}
\hline Skor & Kategori & F & Persentase \\
\hline$\geq 21$ & Sangat Tinggi & 91 & 27.1 \\
$17-20$ & Tinggi & 187 & 55.7 \\
\hline $14-16$ & Sedang & 51 & 15.2 \\
\hline $11-13$ & Rendah & 7 & 2.1 \\
\hline$\leq 10$ & Sangat Rendah & 0 & 0 \\
\hline
\end{tabular}

Dapat dilihat bahwa masyarakat cenderung memiliki rentang nilai untuk indikator penataan kendaraan dari skala perilaku disiplin lalu lintas yang paling dominan berada pada kategori tinggi dengan rentang nilai 17 - 20 dan frekuensi sebanyak 187 masyarakat atau sekitar 55.7 persen. Hal ini menunjukkan masyarakat Kota Samarinda Provinsi Kalimantan Timur memiliki penataan kendaraan yang tergolong tinggi.

Tabel 4. Kategorisasi skor indikator penata jalan dan rambu lalu lintas

\begin{tabular}{cccc}
\hline Skor & Kategori & F & Persentase \\
\hline$\geq 47$ & Sangat Tinggi & 78 & 23.2 \\
$39-46$ & Tinggi & 206 & 61.3 \\
\hline $32-38$ & Sedang & 51 & 15.2 \\
\hline $25-31$ & Rendah & 1 & 0.3 \\
\hline$\leq 25$ & Sangat Rendah & 0 & 0 \\
\hline
\end{tabular}

Dapat dilihat bahwa masyarakat cenderung memiliki rentang nilai untuk indikator penata jalan dan rambu lalu lintas dari skala perilaku disiplin lalu lintas yang paling dominan berada pada kategori tinggi dengan rentang nilai 39-46 dan frekuensi sebanyak 206 masyarakat atau sekitar 61.3 persen. Hal ini menunjukkan masyarakat Kota Samarinda Provinsi Kalimantan Timur memiliki penata jalan dan rambu lalu lintas yang tinggi. 
Tabel 5. Data hasil temuan perilaku disiplin berlalu lintas menyebabkan kecelakaan lalu lintas

\begin{tabular}{|c|c|c|c|c|c|}
\hline $\begin{array}{c}\text { Perilaku Disiplin } \\
\text { Berlalu Lintas }\end{array}$ & Umum & \multicolumn{4}{|c|}{ Khusus } \\
\hline Kualitas Individu & $\begin{array}{l}\text { Pengendara sepeda } \\
\text { motor melaju } \\
\text { kencang tidak } \\
\text { mampu } \\
\text { mengendalikan } \\
\text { kendaraannya, } \\
\text { kurangnya } \\
\text { konsentrasi, } \\
\text { mengantuk pada } \\
\text { saat mengendarai } \\
\text { sepeda motor, } \\
\text { berpindah jalur } \\
\text { tanpa } \\
\text { memperhatikan sisi } \\
\text { kanan dan kiri } \\
\text { jalan. }\end{array}$ & $\begin{array}{l}\text { - Pengemudi sepeda motor } \\
\text { mendahului pengendara } \\
\text { sepeda motor lainnya } \\
\text { (melaju kencang) terlalu } \\
\text { mengambil jalur kekanan } \\
\text { sehingga terjadi laka } \\
\text { lantas } \\
\text { - Pada saat memotong arah } \\
\text { pengemudi sepeda motor } \\
\text { tidak konsentrasi dan } \\
\text { tidak memperhatikan } \\
\text { kendaraan yang berada } \\
\text { dijalur utama. } \\
\text { Selanjutnya terjadi } \\
\text { tabrakan antara sepeda } \\
\text { motor dan terjadilah } \\
\text { kecelakaan lalu lintas } \\
\text { karena mengantuk, } \\
\text { sepeda motor menabrak } \\
\text { bagian belakang mobil } \\
\text { dan terjadilah kecelakaan } \\
\text { lalu lintas }\end{array}$ & $\begin{array}{l}\text { Pada saat yang bersamaan } \\
\text { dari arah selatan menuju } \\
\text { arah utara datang pejalan } \\
\text { kaki yang sedang } \\
\text { menyebrang jalan. Karena } \\
\text { pada saat berjalan lurus } \\
\text { pengemudi tidak } \\
\text { konsentrasi Selanjutnya } \\
\text { terjadi tabrakan antara } \\
\text { keduanya dan terjadilah } \\
\text { kecelakaan lalu lintas. } \\
\text { Karena pada saat berjalan } \\
\text { lurus pengemudi sepeda } \\
\text { motor tidak tertib dan } \\
\text { kurang konsentrasi dengan } \\
\text { tidak memperhatikan } \\
\text { kendaraan yang masuk } \\
\text { kedalam perumahan. } \\
\text { Selanjutnya sepeda motor } \\
\text { menabrak bagian sebelah } \\
\text { kiri mobil dan terjadilah } \\
\text { kecelakaan lalu lintas }\end{array}$ & $\begin{array}{l}\text { Karena pada saat } \\
\text { mendahului pejalan kaki } \\
\text { pengemudi mobil truk } \\
\text { kurang konsentrasi tidak } \\
\text { menjaga keselamatan } \\
\text { pejalan kaki. Selanjutnya } \\
\text { mobil truk membentur } \\
\text { bagian kanan pejalan } \\
\text { kaki dan terjadilah } \\
\text { kecelakaan lalul intas } \\
\text { Karena pada saat } \\
\text { menikung ke arah kiri } \\
\text { pengemudi sepeda motor } \\
1 \text { tidak konsentrasi dan } \\
\text { larut ke arah kanan. } \\
\text { Selanjutnya sepeda } \\
\text { motor } 2 \text { demi } \\
\text { menghindari sepeda } \\
\text { motor } 1 \text { akhirnya } \\
\text { menabrak mobil dan } \\
\text { terjadilah kecelakaan lalu } \\
\text { lintas. }\end{array}$ & $\begin{array}{l}\text { Pada saat yang } \\
\text { bersamaan datang dari } \\
\text { arah timur menuju } \\
\text { arah barat datang } \\
\text { pejalan kaki yang } \\
\text { sedang menyebrang } \\
\text { jalan. Karena pada } \\
\text { saat berjalan lurus } \\
\text { pengemudi sepeda } \\
\text { motor tidak } \\
\text { konsentrasi dan tidak } \\
\text { menjaga keselamatan } \\
\text { pejalan kaki yang } \\
\text { sedang menyebrang } \\
\text { jalan. Terjadilah } \\
\text { lakalantas }\end{array}$ \\
\hline $\begin{array}{l}\text { Penataan } \\
\text { Kendaraan }\end{array}$ & $\begin{array}{l}\text { Kurang } \\
\text { memperhatikan } \\
\text { kondisi kendaraan } \\
\text { misalnya ban }\end{array}$ & $\begin{array}{l}\text { Pada saat berjalan } \\
\text { menikung kearah kanan } \\
\text { ban mobil mengalami } \\
\text { pecah ban. Pada saat } \\
\text { mengalami pecah ban } \\
\text { pengemudi mobil tidak } \\
\text { dapat mengatasi } \\
\text { kemudinya, selanjutnya } \\
\text { mobil mengalami lepas }\end{array}$ & & & \\
\hline
\end{tabular}


Traffic Accident Research Centre

\begin{tabular}{|c|c|c|c|c|c|}
\hline \multirow{2}{*}{$\begin{array}{l}\text { Perilaku Disiplin } \\
\text { Berlalu Lintas }\end{array}$} & \multirow[t]{2}{*}{ Umum } & \multicolumn{4}{|c|}{ Khusus } \\
\hline & & $\begin{array}{l}\text { kendali dan oleng kearah } \\
\text { kiri. }\end{array}$ & & & \\
\hline $\begin{array}{c}\text { Penataan jalan } \\
\text { dan Rambu Lalu } \\
\text { Lintas }\end{array}$ & $\begin{array}{l}\text { Memarkir } \\
\text { kendaraan dibahu } \\
\text { jalan sehingga } \\
\text { menghalangi } \\
\text { penggunaan jalan } \\
\text { lain, berbelok } \\
\text { kanan (kurang } \\
\text { memperhatikan } \\
\text { sekitaran jalan) dan } \\
\text { melawan arus jalan. }\end{array}$ & $\begin{array}{l}\text { Pada saat parkir dibadan } \\
\text { jalan posisi mobil } 1 \text { berada } \\
\text { dibahu jalan dan } \\
\text { menghalangi pengguna jalan } \\
\text { yang lainnya. Selanjutnya } \\
\text { pada saat berjalan lurus } \\
\text { mobil } 2 \text { tidak dapat } \\
\text { menghindari mobil } 1 \\
\text { tersebut. Selanjutnya mobil } \\
2 \text { menabrak bagian belakang } \\
\text { mobil } 1 \text { dan terjadilah } \\
\text { kecelakaan lalu lintas. }\end{array}$ & $\begin{array}{l}\text { Satu arah datang mobil truk } \\
\text { yang bermaksud berbelok } \\
\text { kearah kanan. Namun pada } \\
\text { saat berbelok ke arah kanan } \\
\text { pengemudi mengalami } \\
\text { tabrakan dengan sepeda motor } \\
\text { dan terjadilah kecelakaan lalu } \\
\text { lintas. }\end{array}$ & $\begin{array}{l}\text { Karena pada saat berbelok } \\
\text { pengemudi mobil tidak } \\
\text { memperhatikan kendaraan } \\
\text { yang datang dari arah } \\
\text { belakang. Selanjutnya terjadi } \\
\text { tabrakan antara sepeda } \\
\text { motor dengan mobil dan } \\
\text { terjadilah kecelakaan lalu } \\
\text { lintas. }\end{array}$ & $\begin{array}{l}\text { Satu arah dalam posisi } \\
\text { melawan arus di jalur } \\
\text { sebelah kanan datang } \\
\text { sepeda motor 1. Pada saat } \\
\text { berjalan lurus tiba tiba } \\
\text { sepeda motor } 2 \text { berbelok } \\
\text { kearah kiri menuju arah } \\
\text { timur. Karena pada saat } \\
\text { berpindah jalur } \\
\text { pengemudi sepeda motor } \\
2 \text { tidak memperhatikan } \\
\text { sisi jalan maka kemudian } \\
\text { menabrak sepeda motor } 1 \\
\text { dan terjadilah kecelakaan } \\
\text { lalu lintas }\end{array}$ \\
\hline
\end{tabular}


Adapun uraian data yang didapatkan dari data dokumentasi mengenai kurangnya perilaku disiplin berlalu lintas menyebabkan Laka Lantas (kecelakaan lalu lintas) seperti diperlihatkan pada Tabel 5.

\section{PEMBAHASAN}

Berdasarkan penelitian survey yang telah dilakukan pada bulan April sampai dengan Mei 2019 dari 336 responden menunjukkan bahwa masyarakat Kota Samarinda Provinsi Kalimantan Timur memiliki perilaku disiplin berlalu lintas dominan tinggi yaitu sebanyak 231 masyarakat atau sekitar 68.8 persen. Jika dilihat dari indikator kualitas yang paling dominan berada pada kategori tinggi sebanyak 231 masyarakat atau sekitar 68.8 persen. Hal ini menunjukkan masyarakat Kota Samarinda Provinsi Kalimantan Timur memiliki kualitas individu dalam berkendara yang tergolong tinggi. Artinya individu memiliki kecakapan dan kemampuan yang baik dalam berkendara. Selanjutnya untuk indikator penataan kendaraan yang paling dominan berada pada kategori tinggi sebanyak 187 masyarakat atau sekitar 55.7 persen. Hal ini menunjukkan masyarakat Kota Samarinda Provinsi Kalimantan Timur memiliki penataan kendaraan yang tinggi. Artinya sebagian besar masyarakat memperhatikan kelayakan dan kelengkapan dalam berkendara sebagao syarat amannya seseorang berlalu lintas. Dan untuk indikator penata jalan dan rambu lalu lintas yang paling dominan berada pada kategori tinggi sebanyak 206 masyarakat atau sekitar 61.3 persen. Hal ini menunjukkan masyarakat Kota Samarinda Provinsi Kalimantan Timur memiliki penata jalan dan rambu lalu lintas yang tinggi. Artinya secara umum masyarakat Samarinda kooperatif dan patuh dalam menaati tata jalan dan rambu lalu lintas.

Selanjutnya berdasarkan penelitian studi kasus lakalantas polresta Samarinda hasil temuan dari data dokumentasi yang didapatkan dari Unit Laka Lantas Polres Kota Samarinda tahun 2019 maka dapat disimpulkan bahwa seseorang mengalami Laka Lantas (kecelakaan lalu lintas) dikarenakan beberapa faktor penyebab. Pertama jika ditinjau dari faktor penyebab aspek kualitas atau kecakapan individu dalam berkendara, pengendara sepeda motor yang melaju kencang tidak mampu mengendalikan kendaraannya, kurang konsentrasi, bahkan mengantuk pada saat berkendara, sehingga terjadilah lakantas. Kedua faktor penyebab dari aspek penataan kendaraan meliputi kelengkapan kendaraan seperti mengecek kelengkapan kendaraan sebelum menggunakannya. Aspek ini merupakan faktor penyebab yang paling sedikit menurut data dokumentasi. Hanya satu kejadian kecelakaan yang disebabkan karena aspek penataan kendaraan, yakni kejadian kecelakaan disebabkan oleh ban bocor. Ketika ban bocor atau meledak dijalan, maka membahayakan pengendara sekitar sehingga terjadilah laka lantas. Faktor penyebab ketiga adalah penataan jalan dan rambu lalu lintas meliputi mentaati tata jalan dan rambu lalu lintas seperti jangan memarkir kendaraan di bahu jalan sehingga menghalangi penggunaan jalan lain, kemudian mentaati tata jalan seperti berbelok kanan namun kurang memperhatikan kondisi di sisi dan sekitaran jalan serta melawan arus jalan.

Hal di atas sejalan dengan yang dikemukakan oleh Hobs dalam Azizirrahman, (2015) mengemukakan bahwa faktor penyebab kecelakaan lalu lintas dikelompokkan menjadi tiga kelompok yaitu pertama faktor manusia, yakni faktor yang dapat dilihat dari pengguna kendaraan bermotor, seperti berkendara dengan kecepatan tinggi/ ugal-ugalan, muatan yang berlebihan, dan tidak tertib (tidak memakai helm, melanggar rambu lalu lintas, berbelok tanpa memperhatikan marka jalan). Kedua faktor kendaraan, faktor yang dapat dilihat dari kendaraan, misalnya kondisi ban, kaca spion, dan lampu kendaraan (lampu 
utama, lampu indikator/sein dan lampu rem), dalam hal ini pengecekan kelengkapan kendaraan. Ketiga faktor lingkungan yaitu fisik jalan. Faktor yang dapat dilihat dari jalan, yaitu: jalan rusak, jalan berlubang, jalan tergenang, jalan gelap, tanpa marka/rambu jalan, dan tikungan tajam.

Berdasarkan data dokumentasi Unit Laka Lantas Polresta Samarinda, sebagian besar kecelakaan disebabkan oleh faktor manusia, yakni terkait dengan konsentrasi dalam berkendara dan kepatuhan terhadap tata tertib serta rambu-rambu lalu lintas. Oleh sebab itu untuk mengurangi terjadinya laka lantas baik pemerintah Kota Samarinda maupun pihak Polresta Samarinda bagian lalu lintas perlu memberikan sosialisasi terkait pentingnya perilaku disiplin berlalu lintas serta adanya tindakan yang tegas bagi pengendara yang melanggar tata tertib lalu lintas.

\section{KESIMPULAN}

Berdasarkan penelitian yang telah dilakukan, maka dapat disimpulkan bahwa:

1. Dari 336 responden sebanyak 68.8 persen masyarakat Kota Samarinda Provinsi Kaltim cenderung memiliki perilaku disiplin berlalu lintas yang tinggi.

2. Dari 336 responden sebanyak 231 masyarakat atau sekitar 68.8 persen masyarakat Kota Samarinda Provinsi Kalimantan Timur memiliki kualitas individu yang tinggi.

3. Dari 336 responden Sebanyak 187 masyarakat atau sekitar 55.7 persen masyarakat Kota Samarinda Provinsi Kalimantan Timur memiliki penataan kendaraan yang tinggi.

4. Dari 336 responden sebanyak 206 masyarakat atau sekitar 61.3 persen masyarakat Kota Samarinda Provinsi Kalimantan Timur memiliki penata jalan dan rambu lalu lintas yang tinggi.

5. Penyebab kecelakaan lalu lintas utamanya disebabkan karena faktor manusia, yakni terkait dengan konsentrasi dalam berkendara dan kepatuhan terhadap tata tertib serta rambu-rambu.

\section{DAFTAR PUSTAKA}

Ahmadi, A. (1994). Peranan Pendidikan Di Bidang Keselamatan Lalu Lintas Dan Angkutan Dalam Makalah Seminar Keselamatan Lalu Lintas Jalan. Jakarta : Dephub Aizzirahman, M., Normelani, E., \& Arisanty, D. (2015). Faktor Penyebab Terjadinya Kecelakaan Lalu Lintas Pada Daerah Rawan Kecelakaan Di Kecamatan Banjarimasin Tengah Kota Banjarmasin. Jurnal Pendidikan Geografi.2(3), 20-37

Ancok, D. (2004). Psikologi Terapan. Yogyakarta: Darussalam.

Creswell, J.W., dan Clark, V.L. P. (2011). Designing and Conducting Mixed Methods Research 2nd Edition. Amerika: SAGE

Hidayah, N. (2015). Disiplin Lalu Lintas Pengendara Sepeda Motor Roda Dua Di Kecamatan Tampan Pekanbaru. Jurnal Psikologi Indonesia. 4 (3), 12-27

Maulana, A. (2019 Januari 18). Jumlah Kecelakaan Lalu Lintas Di Indonesia Harus Turun. Kompas.Com, P.1

Priambodo, S. (1997). Disiplin Itu Indah. Jakarta : PT.Gramedia

Sari, Y. P., \& Widodo, H. (2014). Upaya Polisi Lalu Lintas Dalam Meningkatkan Kedisiplinan Berlalu Lintas Pengendara Bermotor (Studi Deskriptif Terhadap Program Kanalisasi Lajur Kiri Pada Satlantas Polrestabes Surabaya). Jurnal Kajian Moral Dan Kewarganegaraan. 2(2), 564-578 